\title{
Occurrence of Carabid Beetles in the Phenological Stages of Weedy Plants
}

\author{
Francisco J. Cividanes ${ }^{1 *}$, Terezinha M. dos Santos-Cividanes ${ }^{2}$, Alex A. Ribeiro ${ }^{1}$ \\ ${ }^{1}$ Plant Protection Department, Paulista State University, Jaboticabal, Brazil \\ ${ }^{2}$ São Paulo Agency for Agribusiness Technology, Ribeirão Preto, Brazil \\ Email: ^fj.cividanes@unesp.br
}

How to cite this paper: Cividanes, F.J., dos Santos-Cividanes, T.M. and Ribeiro, A.A. (2018) Occurrence of Carabid Beetles in the Phenological Stages of Weedy Plants. Advances in Entomology, 6, 176-188. https://doi.org/10.4236/ae.2018.62014

Received: March 11, 2018

Accepted: April 27, 2018

Published: April 30, 2018

Copyright $\odot 2018$ by authors and Scientific Research Publishing Inc. This work is licensed under the Creative Commons Attribution International License (CC BY 4.0).

http://creativecommons.org/licenses/by/4.0/ Open Access

\begin{abstract}
In the current study, we investigated the relationship between the abundance of carabid species (Coleoptera: Carabidae) and the phenological stages of weedy plants growing in edge habitats. A survey of carabid beetles was conducted in edge habitats between forest fragments and soybean/corn crops or orange orchards in five sites located in northeastern São Paulo state, Brazil, from November 2005 to May 2008. Beetles were captured with pitfall traps, and multiple regression analysis was used to determine the carabid species that prevailed on each of the phenological stages of weeds. In total, 1115 individuals, representing 26 genera and 52 species, were captured. Selenophorus species, mainly Selenophorus seriatoporus Putzeys, Selenophorus sp.4, Helluomorphoides squiresi (Chaudoir), Tetragonoderus laevigatus Chaudoir, Athrostictus sp.1 were abundant during the reproductive phenological stages of weedy plants, which suggests that these carabid species might prefer to feed on the seeds of weedy plants.
\end{abstract}

\section{Keywords}

Abundance, Ground Beetle, Phenology, Seed Consumption, Weed

\section{Introduction}

Several studies of plant phenology and insects have focused on the relationship between plants and the life cycle or population dynamics of phytophagous insects [1] [2] [3] [4] [5]. Published studies on the influence of plant phenology on carabid beetles (Coleoptera: Carabidae) have examined the consumption of weed seeds by carabid species, as well as the role of weeds as a refuge and dispersal aid for carabids in agroecosystems [6] [7] [8]. There are also reports of weedy plants 
causing changes in the carabid community structure [9] [10].

Feeding habits of carabid beetles range from carnivory to phytophagy, but there are also carabid species with more-specialized feeding behaviors [11]. For example, in terms of phytophagy, carabids can be classified into two groups: 1) those that are carnivorous but supplement their diets with vegetation; and 2) those that are seed consumers [8] [12] [13]. Thus, in addition to being recognized as important biological control agents of crop pests, carabids are also an important group of seed feeders and, thus, can act efficiently to reduce the size of weed populations in agroecosystems [8] [14]. Carabids and crickets dominate the granivorous taxa of temperate regions [7] [8] [15], whereas ants are dominant in the tropics [16]. Among the carabid beetles, the Harpalini and Zabrini tribes contain the most granivores [6] [17].

Despite the rich carabid fauna in Brazilian agroecosystems [18] [19], there are no specific studies from this region on carabid beetles as weed seed consumers or on their relationship with the phenological stages of weedy plants. The only studies published on the feeding habits of Brazilian carabids were by Barbosa et al. [20], who evaluated the effect of different diet types on biological aspects of two carabid species, and Matta et al. [21], who determined the types of food within the digestive tract of carabids associated with herbaceous plants and colored cotton. It is also worth noting that the life cycle of Brazilian carabids inhabiting agroecosystems is almost unknown; however there is information available about seasonal activity of several dominant carabid species in the state of São Paulo [22].

Therefore, in the current study, a survey of adult carabids was carried out in the edge habitat covered by weedy plants and located between a forest fragment and a soybean/corn crop or an orange orchard in five sites in northeastern São Paulo state, Brazil. The objective was to determine the changes in the density of carabid species in relation to different phenological stages of weeds. We considered the increased number of individuals of a carabid species during the reproductive stages of weedy plants, an indication of preference to feed on seeds of agricultural weeds.

\section{Material and Methods}

\subsection{Sites Description}

The study was carried out in five sites in the northeast region of São Paulo state, Brazil, from November 2005 to May 2008. According to the Köppen system, the regional climate is classified as Aw climate, tropical rainy with dry winter [23]. The first site, in the Jaboticabal municipality [Jaboticabal-no-tillage system (NTS)] was located on the campus of the Universidade Estadual Paulista $\left(21^{\circ} 14^{\prime} 52^{\prime \prime} \mathrm{S}, 48^{\circ} 16^{\prime} 04^{\prime \prime} \mathrm{W}\right)$. The soil is classified as an oxisol. The site comprised 40 ha cultivated with soybean [Glycine $\max$ (L.) Merrill] rotated with corn [Zea mays (L.)], in a NTS, adjacent to 15 ha of a semideciduous broadleaf tropical forest fragment. Two further sites were located in the Guaíra municipality: 
Guaíra-NTS $\left(20^{\circ} 21^{\prime} 10^{\prime \prime S}, 48^{\circ} 14^{\prime} 47^{\prime \prime} \mathrm{W}\right)$ and Guaíra-conventional-tillage system (CTS; $20^{\circ} 19^{\prime} 29^{\prime \prime S}, 48^{\circ} 15^{\prime} 08^{\prime \prime} \mathrm{W}$ ), located approximately $2 \mathrm{~km}$ from one another. The soil is also classified as an oxisol in both sites. Guaíra-NTS comprised a 90-ha field cultivated with soybean rotated with corn, in a NTS, adjacent to 48 ha of a semideciduous broadleaf tropical forest fragment. Guaíra-CTS was a 15-ha site cultivated with soybean rotated with corn in a CTS, adjacent to 6 ha of a semi-deciduous broadleaf tropical forest fragment. The fourth site, the Gavião Peixoto-orange orchard $\left(21^{\circ} 49^{\prime} 19^{\prime \prime} \mathrm{S}, 48^{\circ} 24^{\prime} 46^{\prime \prime} \mathrm{W}\right)$, was located in the Gavião Peixoto municipality. The soil is classified as an ultisol. The site comprised 10 ha of an orange orchard [Citrus sinensis (L.) Osbeck] adjacent to 19 ha of a semideciduous broadleaf tropical forest fragment. The fifth site, Descalvado-orange orchard $\left(21^{\circ} 54^{\prime} 09^{\prime \prime} \mathrm{S}, 47^{\circ} 43^{\prime} 55^{\prime \prime} \mathrm{W}\right)$, was located in the Descalvado municipality. The soil is classified as an oxisol. The site comprised 800 ha of an orange orchard adjacent to 2000 ha of a Brazilian savanna fragment.

In Descalvado and both Guaíra sites, the edge habitat was completely covered by weedy plants, whereas, in the Jaboticabal and Gavião Peixoto sites, the edge habitat contained weeds and a 3-m strip of bare ground. Most of weed species were found in all sites, some of them occurred in 1 or 2 sites only (Table 1).

\subsection{Carabid Beetles and Phenological Stages}

Carabids were sampled with pitfall traps installed in the edge habitat between the forest fragment and soybean/corn crop or orange orchard at each study site, with 50 sampling dates in each sites. Traps were $500-\mathrm{ml}$ (80-mm diameter) plastic cups filled with a solution of formaldehyde in water (1\%) and detergent [19] [21]. To install each trap, a hole was dug and a plastic cup was inserted so that the lip of each cup was level with the ground. A plastic cover (diameter $135 \mathrm{~mm}$ ) was used to protect each trap from rain. A total of eight traps were set in two rows 10-m apart, with each row containing four traps that were set $1 \mathrm{~m}$ apart (Figure 1). Traps were placed in the field twice a month during each cropping season and once per month otherwise. Traps remained in the field for 1 week, at which point the contents were collected. No traps were lost nor destroyed during the sampling period. Beetles were preserved for identification at the Laboratório de Ecologia de Insetos, Universidade Estadual Paulista, Jaboticabal Campus. The carabids were identified to species level by Sérgio Ide, Agência Paulista de Tecnologia dos Agronegócios (APTA), with the help of the keys of Reichardt [24] or by comparison with specimens deposited in the Coleção Entomológica Adolph Hempel, Instituto Biológico, São Paulo (IBSP-IB) and Museu de Zoologia, Universidade de São Paulo, São Paulo. The exemplars are deposited in IBSP-IB.

The phenological stages of weeds were determined by visual inspection of plants performed on the same dates as the carabid samplings. Phenological stages included four stages (vegetative growth, flowering, fruiting, and seed dispersal), 
Table 1. Weed species found in the edge habitat between forest fragment and agricultural fields of five sites. Weeds are listed based on their occurrence in the sites. NTS = no-tillage system, CTS = conventional tillage system.

\begin{tabular}{|c|c|c|c|c|}
\hline \multirow{2}{*}{ Site } & \multicolumn{4}{|c|}{ Weed species } \\
\hline & Scientific name & Common name & Family & Life cycle \\
\hline \multirow[t]{11}{*}{ All sites } & Acanthospermum australe (Loefl.) Kuntze & sheepbur & Asteraceae & annual \\
\hline & Alternanthera tenella Colla & - & Amaranthaceae & perennial \\
\hline & Bidens pilosa $\mathrm{L}$. & beggarticks & Asteraceae & annual \\
\hline & Cenchrus echinatus $\mathrm{L}$. & sandbur & Poaceae & annual \\
\hline & Commelina benghalensis $\mathrm{L}$. & dayflower & Commelinaceae & perennial \\
\hline & Conyza bonariensis (L.) Cronquist & fleabane & Asteraceae & annual \\
\hline & Cyperus rotundus $\mathrm{L}$. & nutsedge & Cyperaceae & perennial \\
\hline & Digitaria insularis (L.) Mex ex Ekman & sourgrass & Poaceae & perennial \\
\hline & Eleusine indica (L.) Gaertner & goosegrass & Poaceae & annual \\
\hline & Emilia sonchifolia (L.) DC. ex Wight & tasselflower & Asteraceae & annual \\
\hline & Sida sp. L. & - & Malvaceae & annual \\
\hline Jaboticabal-NTS & Acanthospermum hispidum DC. & bristly starbur & Asteraceae & annual \\
\hline \multirow[t]{2}{*}{ (soybean/corn crop) } & Digitaria nuda Schumacher & naked crabgrass & Poaceae & annual \\
\hline & Panicum maximum Jacq. & guineagrass & Poaceae & perennial \\
\hline Guaíra-NTS & Brachiaria decumbens Stapf & signal grass & Poaceae & perennial \\
\hline \multicolumn{5}{|l|}{ (soybean/corn crop) } \\
\hline Guaíra-CTS & Brachiaria decumbens Stapf & signal grass & Poaceae & perennial \\
\hline \multicolumn{5}{|l|}{ (soybean/corn crop) } \\
\hline Gavião Peixoto & Brachiaria decumbens Stapf & signal grass & Poaceae & perennial \\
\hline \multirow[t]{2}{*}{ (orange orchard) } & Chamaesyce hirta (L.) Millsp. & spurge & Euphorbiaceae & annual \\
\hline & Parthenium hysterophorus L. & ragweed & Asteraceae & annual \\
\hline Descalvado & Amaranthus sp. L. & - & Amaranthaceae & annual \\
\hline \multirow[t]{4}{*}{ (orange orchard) } & Brachiaria decumbens Stapf & signal grass & Poaceae & perennial \\
\hline & Digitaria nuda Schumacher & naked crabgrass & Poaceae & annual \\
\hline & Panicum maximum Jacq. & guineagrass & Poaceae & perennial \\
\hline & Rhynchelitrum repens (Willd.) C.E. Hubb & natal grass & Poaceae & annual \\
\hline
\end{tabular}

and were established based on Fenner [25]. The inspections were performed using square metal quadrants $(0.70 \times 0.70 \mathrm{~m})$ for the random removal of $18 \mathrm{sam}$ ples in the immediate vicinity of the pitfall traps. The phenological stages of plants inside the quadrant were visually determined according to the following criterion: 1) vegetative growth: plant without reproductive structures, 2) flowering or fruiting stages: presence of at least one flower or fruit, respectively, and 3) 


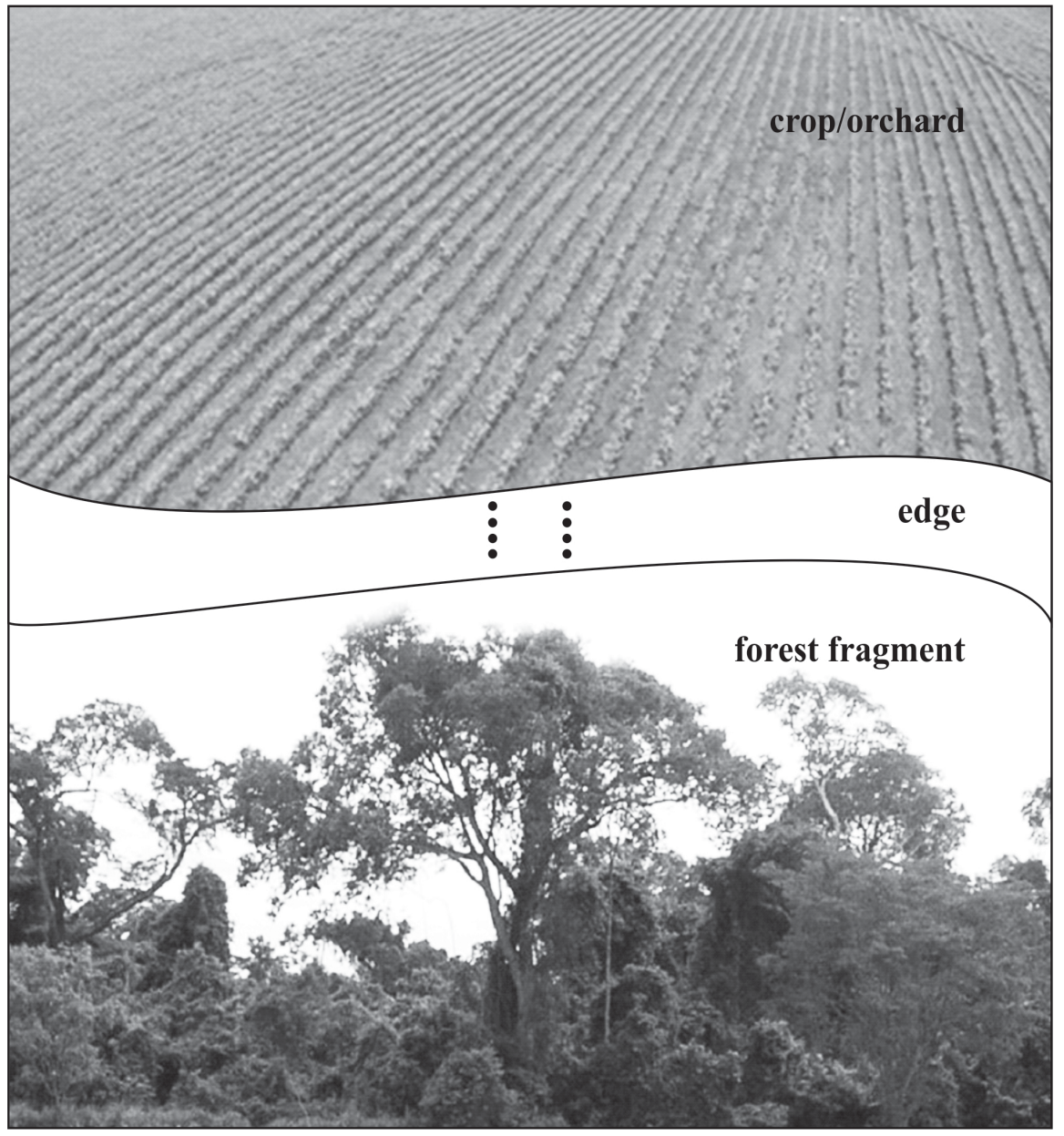

Figure 1. Position of the pitfall traps in the edge between forest fragment and soybean/corn crop or orange orchard. Black dots represent the position of the traps set in two rows $10-\mathrm{m}$ apart, each one containing 4 traps installed at 1-m intervals.

seed dispersal: plant with several seeds. The weed species were identified by Maria do Carmo Morelli Damasceno Pavani, Departamento de Biologia, Faculdade de Ciências Agrárias e Veterinárias, Universidade Estadual Paulista, Jaboticabal Campus, according to Lorenzi [26] and Moreira and Bragança [27].

\subsection{Data Analysis}

The relationship between the phenological stages of the weedy plants and the abundance of carabid species were examined by stepwise multiple regression analysis [28], which included the phenological stages as independent variables. The model used was:

$$
\mathrm{Y}=\mathrm{b}_{0}+\mathrm{b}_{1} \mathrm{X}_{1}+\mathrm{b}_{2} \mathrm{X}_{2}+\mathrm{b}_{3} \mathrm{X}_{3}+\mathrm{b}_{4} \mathrm{X}_{4}
$$

where $b_{1}, b_{2}, b_{3}$, and $b_{4}$ were the coefficients of vegetative growth, flowering, fruiting, and seed dispersal, respectively. The analysis was performed based on the capture of carabids on two distinct dates in relation to plant phenology: 1) 
carabid sampling and observation of phenological stages performed simultaneously; and 2) carabid sampling 1 month after the phenological observations. The analysis was based on the total number of individuals of the carabid species captured in all traps, and the total number of all weed species in each one of the phenological stages throughout the sampling period. SAS 93 software [29] was used for the analysis. Carabid species represented by fewer than ten individuals were excluded from the analysis.

\section{Results}

A total of 1,115 individual carabids, representing 26 genera and 52 species, were captured (Table 2). The three most-abundant carabid species were Abaris basistriata Chaudoir (20.6\% of the total sample), Selenophorus seriatoporus Putzeys (15.8\% of the total sample), and Odontocheila nodicornis (Dejean) (9.6\% of the total sample), while Scarites sp. 3, Selenophorus sp.4, Athrostictus sp.1, and Pentacomia cupricollis (Kollar) accounted for 6.9\%, 5.5\%, 4.6\%, and 4.0\%, respectively, of the total sample.

Multiple regression analysis showed that some carabid populations increased during the reproductive period of the weeds. A population increase was verified in S. seriatoporus (Table 3 ) during the flowering stage of weeds $\left(\mathrm{b}_{2}=0.0941, \mathrm{p}=\right.$ $0.0356)$ in Jaboticabal-NTS, during both the flowering stage $\left(\mathrm{b}_{2}=0.2510, \mathrm{p}=\right.$ $0.0494)$ and fruiting stage $\left(\mathrm{b}_{3}=0.1789, \mathrm{p}=0.0527\right)$ in Guaíra-NTS, and during the seed dispersal stage in Gavião Peixoto $\left(b_{4}=0.0103, p=0.0373\right)$ and Descalvado $\left(\mathrm{b}_{4}=0.0212, \mathrm{p}=0.0360\right)$. Similar population increases were also verified in Selenophorus sp.4 ( $\mathrm{b}_{3}=0.0347, \mathrm{p}=0.0006$; Descalvado $)$ and H. squiresi $\left(\mathrm{b}_{3}=\right.$ $0.0267, \mathrm{p}=0.0042$; Gavião Peixoto) during the fruiting stage of the weeds, and in Athrostictus sp. $1\left(\mathrm{~b}_{2}=0.1765, \mathrm{p}=0.0134\right.$; Jaboticabal $)$ and Tetragonoderus laevigatus Chaudoir $\left(\mathrm{b}_{2}=0.0681, \mathrm{p}=0.0189\right.$; Descalvado) during the flowering stage. The density of these carabid species also increased during the reproductive phenological stages when captured by traps 1 month after the phenological observations (Table 4). This was observed in S. seriatoporus $\left(\mathrm{b}_{2}=0.0154, \mathrm{p}=\right.$ 0.0192; Gavião Peixoto), Selenophorus sp. $1\left(\mathrm{~b}_{2}=0.0200, \mathrm{p}=0.0059\right.$; Jaboticabal-NTS), Selenophorus sp.4 $\left(\mathrm{b}_{3}=0.0166, \mathrm{p}=0.0011\right.$; Guaíra-CTS), Helluomorphoides squiresi (Chaudoir) $\left(\mathrm{b}_{3}=0.0270, \mathrm{p}=0.0135\right)$, and T. laevigatus $\left(\mathrm{b}_{4}=\right.$ $0.0352, \mathrm{p}=0.0362)$ in the Gavião Peixoto and Descalvado sites (Table 4).

The number of Scarites spp. individuals decreased during the reproductive period of weeds, including individuals captured 1 month after the phenological period had been determined (Table 3 and Table 4). Similar population behavior was found in Abaris basistriata Chaudoir captured after a 1-month lag (Table 4). The reverse result was found for Calosoma granulatum (Perty) in the Jaboticabal and Guaíra-NTS sites (Table 3 and Table 4), and for O. nodicornis and Galerita brasiliensis Dejean in the Guaíra-CTS and Descalvado sites, respectively (Table 4). In addition, $O$. nodicornis was abundant in the edge habitats of three of the study sites (Table 2). 
Table 2. Total number of carabid individuals collected in the edge between forest fragment and agricultural field of five sites. NTS = no-tillage system, CTS $=$ conventional tillage system, $\mathrm{ORC}=$ orange orchard .

\begin{tabular}{|c|c|c|c|c|c|c|}
\hline & Species & $\begin{array}{c}\text { Jaboticabal } \\
\text { (NTS) }\end{array}$ & $\begin{array}{l}\text { Guaíra } \\
\text { (NTS) }\end{array}$ & $\begin{array}{l}\text { Guaíra } \\
\text { (CTS) }\end{array}$ & $\begin{array}{c}\text { Gavião Peixoto } \\
\text { (ORC) }\end{array}$ & $\begin{array}{l}\text { Descalvado } \\
\text { (ORC) }\end{array}$ \\
\hline 1 & Abaris basistriata Chaudoir, 1873 & 71 & 43 & 66 & 19 & 31 \\
\hline 2 & Amblygnathus suturalis Putzeys, 1845 & 1 & 0 & 0 & 0 & 0 \\
\hline 3 & Apenes marginalis (Dejean, 1831) & 2 & 0 & 0 & 0 & 0 \\
\hline 4 & Apenes plaumanni (Liebke, 1939) & 1 & 0 & 4 & 2 & 1 \\
\hline 5 & Apenes sp. & 0 & 1 & 0 & 0 & 1 \\
\hline 6 & Athrostictus speciosus Dejean, 1829 & 2 & 0 & 0 & 1 & 0 \\
\hline 7 & Athrostictus aff nobilis Brullé, 1838 & 0 & 0 & 1 & 0 & 0 \\
\hline 8 & Athrostictus sulcatulus Dejean, 1829 & 2 & 0 & 0 & 3 & 0 \\
\hline 9 & Athrostictus sp.1 & 36 & 4 & 0 & 11 & 0 \\
\hline 10 & Barysomus punctatostriatus Emden, 1949 & 0 & 0 & 0 & 1 & 0 \\
\hline 11 & Calosoma granulatum (Perty, 1830) & 13 & 4 & 1 & 3 & 1 \\
\hline 12 & Colliuris sp. & 0 & 0 & 1 & 0 & 0 \\
\hline 13 & Cymindis sp.1 & 0 & 1 & 1 & 0 & 0 \\
\hline 14 & Cynthidia croceipes (Perty, 1830) & 1 & 0 & 0 & 0 & 0 \\
\hline 15 & Galerita brasiliensis Dejean, 1826 & 14 & 0 & 0 & 0 & 12 \\
\hline 16 & Galerita bruchi Liebke, 1932 & 2 & 0 & 0 & 0 & 0 \\
\hline 17 & Galerita occidentalis (Olivier, 1795) & 1 & 2 & 0 & 0 & 0 \\
\hline 18 & Helluobrocus negrei Reichardt, 1974 & 0 & 0 & 0 & 1 & 0 \\
\hline 19 & Helluomorphoides squiresi (Chaudoir, 1872) & 0 & 0 & 0 & 14 & 0 \\
\hline 20 & Loxandrus catharinae Tschitschérine, 1900 & 0 & 0 & 0 & 1 & 0 \\
\hline 21 & Loxandrus sp.1 & 1 & 0 & 2 & 0 & 0 \\
\hline 22 & Loxandrus subvittatus Straneo, 1953 & 14 & 10 & 2 & 1 & 0 \\
\hline 23 & Microcephalus festiva Tschitschérine, 1898 & 0 & 0 & 1 & 0 & 0 \\
\hline 24 & Morion cyclomus Chaudoir, 1854 & 0 & 0 & 1 & 0 & 0 \\
\hline 25 & Notiobia amethystinus Dejean, 1829 & 0 & 0 & 0 & 1 & 0 \\
\hline 26 & Notiobia chalcites Germar, 1824 & 3 & 0 & 0 & 1 & 0 \\
\hline 27 & Notiobia cupripennis (Germar, 1824) & 1 & 0 & 0 & 0 & 0 \\
\hline 28 & Notiobia sp.1 & 0 & 1 & 0 & 2 & 0 \\
\hline 29 & Notiobia sp.2 & 0 & 3 & 1 & 0 & 0 \\
\hline 30 & Odontocheila nodicornis (Dejean, 1825) & 29 & 43 & 30 & 5 & 0 \\
\hline 31 & Pelecium brasiliense Straneo, 1962 & 0 & 2 & 0 & 0 & 0 \\
\hline 32 & Pentacomia cupricollis (Kollar, 1836) & 10 & 30 & 2 & 3 & 0 \\
\hline 33 & Polpochila impressifrons (Dejean, 1831) & 0 & 0 & 0 & 1 & 0 \\
\hline 34 & Pseudabarys sp. 1 & 3 & 0 & 0 & 16 & 0 \\
\hline 35 & Scarites sp.1 & 0 & 0 & 2 & 0 & 0 \\
\hline
\end{tabular}




\section{Continued}

\begin{tabular}{|c|c|c|c|c|c|c|}
\hline 36 & Scarites sp. 2 & 27 & 0 & 0 & 8 & 0 \\
\hline 37 & Scarites sp. 3 & 37 & 20 & 13 & 7 & 0 \\
\hline 38 & Scarites sp. 4 & 0 & 21 & 9 & 0 & 0 \\
\hline 39 & Scarites sulcipes (Chaudoir, 1855) & 0 & 0 & 0 & 8 & 0 \\
\hline 40 & Selenophorus alternans Dejean, 1829 & 11 & 0 & 0 & 1 & 22 \\
\hline 41 & Selenophorus discopunctatus Dejean, 1829 & 5 & 1 & 0 & 2 & 1 \\
\hline 42 & Selenophorus seriatoporus Putzeys, 1878 & 21 & 98 & 20 & 10 & 27 \\
\hline 43 & Selenophorus ventralis Putzeys, 1878 & 0 & 0 & 0 & 0 & 10 \\
\hline 44 & Selenophorus sp. 1 & 6 & 0 & 0 & 1 & 2 \\
\hline 45 & Selenophorus sp.2 & 1 & 0 & 0 & 0 & 0 \\
\hline 46 & Selenophorus sp.4 & 1 & 4 & 15 & 31 & 10 \\
\hline 47 & Selenophorus sp. 5 & 1 & 0 & 0 & 0 & 0 \\
\hline 48 & Stratiotes sp.1 & 4 & 0 & 2 & 0 & 0 \\
\hline 49 & Tetracha brasiliensis (Kirby, 1818) & 24 & 5 & 3 & 7 & 0 \\
\hline 50 & Tetracha sp.1 & 2 & 0 & 0 & 0 & 1 \\
\hline 51 & Tetragonoderus laevigatus Chaudoir, 1876 & 0 & 0 & 0 & 0 & 17 \\
\hline 52 & Tetragonoderus sp. 1 & 0 & 0 & 0 & 0 & 2 \\
\hline & Number total of individuals & 347 & 292 & 177 & 161 & 138 \\
\hline & Number of species & 31 & 18 & 20 & 27 & 14 \\
\hline
\end{tabular}

Table 3. Regression coefficients and the standard errors for phenological phases of weedy plants and carabids captured in the edge between forest fragment and agricultural field of five sites. NTS = no-tillage system, CTS = conventional tillage system.

\begin{tabular}{|c|c|c|c|c|c|c|}
\hline \multirow{2}{*}{ Sites } & \multicolumn{6}{|c|}{ Regression coefficients and standard errors } \\
\hline & Species & Vegetative growth & Flowering & Fruiting & Seed dispersal & $\mathrm{F}$ \\
\hline Jaboticabal-NTS & Abaris basistriata & - & $0.2537 \pm 0.08$ & - & - & $9.79^{* *}$ \\
\hline \multirow[t]{3}{*}{ (soybean/corn crop) } & Athrotictus sp.1 & - & $0.1765 \pm 0.07$ & - & - & $6.69^{*}$ \\
\hline & Calosoma granulatum & - & - & $0.0373 \pm 0.02$ & - & $4.63^{\star}$ \\
\hline & Selenophorus seriatoporus & - & $0.0941 \pm 0.04$ & - & - & $4.73^{*}$ \\
\hline Guaíra-NTS & Selenophorus seriatoporus & - & $0.2510 \pm 0.12$ & $0.1789 \pm 0.08$ & - & $4.18^{*}$ \\
\hline \multirow[t]{2}{*}{ (soybean/corn crop) } & Scarites sp. 3 & $-0.0621 \pm 0.02$ & - & - & $-0.0406 \pm 0.02$ & $4.97^{* *}$ \\
\hline & Scarites sp.4 & - & - & $-0.0597 \pm 0.03$ & - & $4.08^{*}$ \\
\hline $\begin{array}{c}\text { Guaíra-CTS } \\
\text { (soybean/corn crop) }\end{array}$ & \multicolumn{6}{|c|}{ No variable was included in the regression model } \\
\hline Gavião Peixoto & Helluomorphoides squiresi & - & - & $0.0267 \pm 0.01$ & - & $9.09^{* *}$ \\
\hline (orange orchard) & Selenophorus seriatoporus & - & - & - & $0.0103 \pm 0.01$ & $4.60^{*}$ \\
\hline Descalvado & Selenophorus seriatoporus & - & $-0.0334 \pm 0.02$ & - & $0.0212 \pm 0.01$ & $4.44^{*}$ \\
\hline (orange orchard) & Selenophorus sp.4 & - & - & $0.0347 \pm 0.01$ & - & $14.14^{* *}$ \\
\hline & Tetragonoderus laevigatus & - & $0.0681 \pm 0.03$ & - & - & $6.04^{*}$ \\
\hline
\end{tabular}

****Indicate significance at the $\mathrm{P}<0.05$ and $\mathrm{P}<0.01$ levels, respectively. 
Table 4. Regression coefficients and the standard errors for phenological phases of weedy plants and carabids captured with a one-month lag in the edge between forest fragment and agricultural field of five sites. NTS = no-tillage system, CTS = conventional tillage system.

\begin{tabular}{|c|c|c|c|c|c|c|}
\hline \multirow{2}{*}{ Sites } & \multicolumn{6}{|c|}{ Regression coefficients and standard errors } \\
\hline & Species & Vegetative growth & Flowering & Fruiting & Seed dispersal & $\mathrm{F}$ \\
\hline Jaboticabal-NTS & Selenophorus sp. 1 & - & $0.0200 \pm 0.01$ & - & - & $8.58^{* *}$ \\
\hline (soybean/corn crop) & Scarites sp. 3 & - & - & $-0.0841 \pm 0.03$ & $-0.0461 \pm 0.03$ & $4.13^{*}$ \\
\hline Guaíra-NTS & Abaris basistriata & $0.0450 \pm 0.02$ & $-0.1508 \pm 0.07$ & - & - & $3.69^{*}$ \\
\hline \multirow[t]{2}{*}{ (soybean/corn crop) } & Calosoma granulatum & - & $-0.0163 \pm 0.01$ & $0.0207 \pm 0.01$ & - & $11.03^{* *}$ \\
\hline & Scarites sp. 4 & $0.0657 \pm 0.02$ & - & $-0.0983 \pm 0.03$ & - & $8.01^{\star *}$ \\
\hline Guaíra-CTS & Apenes aenea & $0.0102 \pm 0.01$ & - & $-0.0231 \pm 0.01$ & - & $6.16^{\star *}$ \\
\hline \multirow[t]{2}{*}{ (soybean/corn crop) } & Odontocheila nodicornis & - & $0.0783 \pm 0.04$ & - & - & $4.36^{*}$ \\
\hline & Selenophorus sp. 4 & - & - & $0.0166 \pm 0.01$ & - & $12.71^{\star *}$ \\
\hline Gavião Peixoto & Abaris basistriata & $-0.0166 \pm 0.01$ & - & - & $-0.0286 \pm 0.01$ & $3.57^{\star}$ \\
\hline \multirow[t]{2}{*}{ (orange orchard) } & Helluomorphoides squiresi & - & - & $0.0270 \pm 0.01$ & - & $6.64^{*}$ \\
\hline & Selenophorus seriatoporus & - & $0.0154 \pm 0.02$ & - & - & $5.92^{*}$ \\
\hline Descalvado & Abaris basistriata & $-0.0437 \pm 0.02$ & $-0.1175 \pm 0.04$ & - & $-0.0947 \pm 0.03$ & $6.01^{\star *}$ \\
\hline \multirow[t]{2}{*}{ (orange orchard) } & Galerita brasiliensis & $-0.0042 \pm 0.01$ & - & $0.0107 \pm 0.01$ & - & $6.68^{* *}$ \\
\hline & Tetragonoderus laevigatus & - & - & - & $0.0352 \pm 0.02$ & $4.71^{\star}$ \\
\hline
\end{tabular}

*** Indicate significance at the $\mathrm{P}<0.05$ and $\mathrm{P}<0.01$ levels, respectively.

\section{Discussion}

Most carabids feed on a variety of invertebrates, but there are some species that consume weed seeds [8] [11]. In a previous study that evaluated the predatory potential of adult carabid beetles [30], Athrostictus sp.1, H. squiresi, T. laevigatus, and Selenophorus spp. demonstrated low predatory potential on A. gemmatalis larvae, a major soybean pest in Brazil. Thus, the increase in abundance of Athrostictus sp.1, H. squiresi, S. seriatoporus, Selenophorus sp.1, Selenophorus sp.4, and T. laevigatus during the reproductive stages of weeds recorded in the current study might be related to their preference to feed on seeds from weeds. Selenophorus spp. are recognized for feeding on seeds of weeds [6]. For example, S. seriatoporus was reported to consume seeds of signal grass, Brachiaria decumbens Stapf [20]. In addition, the genera Athrostictus and Selenophorus belong to the Harpalini tribe, which is one of the tribes with the most granivores [6] [17]. Helluomorphoides squiresi and T. laevigatus belong to the Helluinini and Cyclosomini tribes, respectively, which, together with Harpalini, are included in the Harpalitae supertribe [31]. It is also noted that the population increase verified in S. seriatoporus, Selenophorus sp.1, Selenophorus sp.4, H. squiresi, and T. laevigatus 1 month after the phenological observations could also be an evidence of their preference for weed seeds, given that the fruiting and seed-dispersal stages of these plants lasted for up to 6 months in each of the 
study sites. As carabids are important weed biological control agents [8], further studies are required to confirm whether Athrostictus sp.1, H. squiresi, T. laevigatus, and species of Selenophorus feed on weed seeds in this region.

The low number of $A$. basistriata and Scarites spp. individuals during the reproductive period of weeds, and the previous finding that these carabids demonstrate great predatory potential on A. gemmatalis larvae [30], suggest that such species have a low preference for weed seeds. By contrast, the presence of $C$. granulatum, G. brasiliensis, and $O$. nodicornis in the edge habitats suggests that these habitats act as temporary refuges for these species [32] [33]. This is also supported by reports that $C$. granulatum prefers soybean/corn crops and is rarely observed in forest fragments and that $O$. nodicornis behaves as a forest species [19], whereas G. brasiliensis occurs mainly in corn crops rather than in rubber tree plantations (Hevea brasiliensis Muell Arg) or soybean crops [34].

The abundance of carabid beetles usually increases throughout the growing season, with multiple drivers responsible for this increase. In the current study, 52 carabid species were found in the edge habitats between forest fragments and soybean/corn crops or orange orchards. The carabid populations in this environment are likely to have been exposed to similar temperatures and types of food across each study site. However, those carabid species showed different behaviors in relation to the phenological stages of the weedy plants. Some carabids (Athrostictus sp.1, H. squiresi, T. laevigatus, and species of Selenophorus, mainly S. seriatoporus and Selenophorus sp.4), increased in abundance during the reproductive stages of weeds and showed low or no preference for $A$. gemmatalis larvae [30]. Such behavior might suggest that those carabid species prefer to feed on weed seeds. By contrast, the populations of A. basistriata, C. granulatum, $G$. brasiliensis, $O$. nodicornis, and Scarites spp. decreased during the reproductive period of weeds and/or demonstrated high predation of $A$. gemmatalis larvae [30]; such findings suggest that those carabid species had a low preference for weed seeds. Finally, it should be emphasized that all weed species observed in the present study were only found in the edge of all five sites; however these weeds are commonly found in the interior of most Brazilian agricultural fields. Here, the weeds did not penetrate the studied fields/orchards because they were controlled by herbicides in the crop fields while the presence of spontaneous vegetation covering the soil surface of the orchards prevented the development of these plants.

\section{Acknowledgements}

We thank Sérgio Ide and Maria C. M. D. Pavani for the identification of carabid species and weedy plants, respectively; we also thank Ivan C. Martins and Robson J. da Silva for help in the field work. This study was funded by the Fundação de Amparo à Pesquisa do Estado de São Paulo (FAPESP), grant 2003/06577-6, and the Conselho Nacional de Desenvolvimento Científico e Tecnológico (CNPq), grant 472723/2004-9. CNPq also provided a scholarship to the first author, grant 301735/2012-3. 


\section{References}

[1] Peterson, M.A. (1997) Host Plant Phenology and Butterfly Dispersal: Causes and Consequences of Uphill Movement. Ecology, 78, 167-180. https://doi.org/10.1890/0012-9658(1997)078[0167:HPPABD]2.0.CO;2

[2] Kurota, H. and Shimada, M. (2002) Geographical Variation in the Seasonal Population Dynamics of Bruchidius dorsalis (Coleoptera: Bruchidae): Constraints of Temperature and Host Plant Phenology. Environmental Entomology, 31, 469-475. https://doi.org/10.1603/0046-225X-31.3.469

[3] Bourchier, R.S. and Crowe, M.L. (2011) Role of Plant Phenology in Mediating Interactions between Two Biological Control Agents for Spotted Knapweed. Biological Control, 58, 367-373. https://doi.org/10.1016/j.biocontrol.2011.05.003

[4] Sadakiyo, S. and Ishihara, M. (2011) Rapid Seasonal Adaptation of an Alien Bruchid after Introduction: Geographic Variation in Life Cycle Synchronization and Critical Photoperiod for Diapause Induction. Entomologia Experimentalis et Applicata, 140, 69-76. https://doi.org/10.1111/j.1570-7458.2011.01136.x

[5] Koch, R.L. and Rich, W.A. (2015) Stink Bug (Hemiptera: Heteroptera: Pentatomidae) Feeding and Phenology on Early-Maturing Soybean in Minnesota. Journal of Economic Entomology, 108, 2335-2343. https://doi.org/10.1093/jee/tov218

[6] Tooley, J. and Brust, G.E. (2002) Weed Predation by Carabid Beetles. In: Holland, J.M., Ed., The Agroecology of Carabid Beetles, Intercept, Andover, 215-229.

[7] O’Rourke, M.E., Heggenstaller, A.H., Liebman, M. and Rice, M.E. (2006) Post-Dispersal Weed Seed Predation by Invertebrates in Conventional and Low-External-Input Crop Rotation Systems. Agriculture, Ecosystems \& Environment, 116, 280-288. https://doi.org/10.1016/j.agee.2006.02.018

[8] Kulkarni, S.S., Dosdallm, L.M. and Willenborg, C.J. (2015) The Role of Ground Beetles (Coleoptera: Carabidae) in Weed Seed Consumption: A Review. Weed Science, 63, 355-376. https://doi.org/10.1614/WS-D-14-00067.1

[9] Gu, W., Sang, W., Liang, H. and Axmacher, J.C. (2008) Effects of Crofton Weed Ageratina adenophora on Assemblages of Carabidae (Coleoptera) in the Yunnan Province, South China. Agriculture, Ecosystems \& Environment, 124, 173-178. https://doi.org/10.1016/j.agee.2007.09.004

[10] Hansen, A.K., Ortega, Y.K. and Six, D.L. (2009) Comparison of Ground Beetle (Coleoptera: Carabidae) Assemblages in Rocky Mountain Savannas Invaded and Un-Invaded by an Exotic Forb, Spotted Knapweed. Northwest Science, 3, 348-360. https://doi.org/10.3955/046.083.0406

[11] Lundgren, J.G. (2009) Relationships of Natural Enemies and Non-Prey Foods. In: Lundgren, J.G., Progress in Biological Control, Springer, Brookings, 143-165.

[12] Lövei, G.L. and Sunderland, K.D. (1996) Ecology and Behavior of Ground Beetles (Coleoptera: Carabidae). Annual Review of Entomology, 41, 231-256. https://doi.org/10.1146/annurev.en.41.010196.001311

[13] Kromp, B. (1999) Carabid Beetles in Sustainable Agriculture: A Review on Pest Control Efficacy, Cultivation Impacts and Enhancement. Agriculture, Ecosystems \& Environment, 74, 187-228. https://doi.org/10.1016/S0167-8809(99)00037-7

[14] Menalled, F.D., Smith, R.G., Dauer, J.T. and Fox, T.B. (2007) Impact of Agricultural Management on Carabid Communities and Weed Seed Predation. Agriculture, Ecosystems \& Environment, 118, 49-54. https://doi.org/10.1016/j.agee.2006.04.011

[15] Lundgren, J.G., Shaw, J.T., Zaborski, E.R. and Eastman, C.E. (2006) The Influence of Organic Transition Systems on Beneficial Ground Dwelling Arthropods and 
Predation of Insects and Weed Seeds. Renewable Agriculture and Food Systems, 21, 227-237. https://doi.org/10.1079/RAF2006152

[16] Albert, M.J., Escudero, A. and Iriondo, J.M. (2005) Assessing Ant Seed Predation in Threatened Plants: A Case Study. Acta Oecologica, 28, 213-220. https://doi.org/10.1016/j.actao.2005.04.005

[17] Honek, A., Martinkova, Z., Saska, P. and Pekar, S. (2007) Size and Taxonomic Constraints Determine the Seed Preferences of Carabidae (Coleoptera). Basic and Applied Ecology, 8, 343-353. https://doi.org/10.1016/j.baae.2006.07.002

[18] Cividanes, F.J., Araújo, E.S., Ide, S. and Galli, J.C. (2010) Distribution and Habitat Preference of Carabidae and Staphylinidae (Coleoptera) in an Orange Orchard and a Forest Fragment. Florida Entomologist, 93, 339-345.

https://doi.org/10.1653/024.093.0303

[19] Martins, I.C.F., Cividanes, F.J., Ide, S. and Haddad, G.Q. (2012) Diversity and Habitat Preferences of Carabidae and Staphylinidae (Coleoptera) in Two Agroecosystems. Bragantia, 71, 471-480. https://doi.org/10.1590/S0006-87052013005000009

[20] Barbosa, C.L., Cividanes, F.J., Andrade, D.J. and Santos-Cividanes, T.M. (2012) Effect of Diets on Biology of Abaris basistriata and Selenophorus seriatoporus (Coleoptera: Carabidae). Annals of the Entomological Society of America, 105, 54-59. https://doi.org/10.1603/AN11039

[21] Matta, D.H., Cividanes, F.J., Silva, R.J., Batista, M.N., Otuka, A.K., Correia, E.T. and Matos, S.T.S. (2017) Feeding Habits of Carabidae (Coleoptera) Associated with Herbaceous Plants and the Phenology of Coloured Cotton. Acta Scientiarum Agronomy, 39, 135-142. https://doi.org/10.4025/actasciagron.v39i2.32593

[22] Cividanes, F.J., Santos-Cividanes, T.M. dos and Barbosa, J.C. (2016) Seasonal Activity of Carabidae (Coleoptera) in Forest Fragments and Crops in São Paulo, Brazil. The Coleopterists Bulletin, 70, 638-644. https://doi.org/10.1649/0010-065X-70.3.638

[23] de Rolim, G.S., de Camargo, M.B.P., Lania, D.G. and de Moraes, J.F.L. (2007) Classificação climática de Köppen e de Thornthwaite e sua aplicabilidade na determinação de zonas agroclimáticas para o estado de São Paulo. Bragantia, 66, 711-720. https://doi.org/10.1590/S0006-87052007000400022

[24] Reichardt, H. (1977) A Synopsis of the Genera of Neotropical Carabidae (Insecta: Coleoptera). Quaestiones Entomologicae, 13, 346-493.

[25] Fenner, M. (1998) The Phenology of Growth and Reproduction in Plants. Perspectives in Plant Ecology, Evolution and Systematics, 1, 78-91. https://doi.org/10.1078/1433-8319-00053

[26] Lorenzi, H. (2006) Manual de Identificação e Controle de Plantas Daninhas: Plantio Direto e Convencional. 6th Edition, Instituto Plantarum de Estudos da Flora, Nova Odessa.

[27] Moreira, H.J.C. da and Bragança, H.B.N. (2011) Manual de Identificação de Plantas Infestantes: Hortifrúti. FMC Agricultural Products, Campinas.

[28] Draper, N.R. and Smith, H. (1998) Applied Regression Analysis. John Wiley, New York. https://doi.org/10.1002/9781118625590

[29] SAS Institute Inc. (2011) SAS/STAT 93 User's Guide. SAS Institute Inc., Cary.

[30] Cividanes, F.J., Ide, S., Ribeiro, A.A. and Santos-Cividanes, T.M. dos (2014) Predatory Potential of Carabidae and Staphylinidae (Coleoptera) on the Velvetbean Caterpillar. Pesquisa Agropecuária Brasileira, 49, 652-655. https://doi.org/10.1590/S0100-204X2014000800010

[31] Bousquet, Y. (2012) Catalogue of Geadephaga (Coleoptera, Adephaga) of America, 
North of Mexico. ZooKeys, 241, 1-1722. https://doi.org/10.3897/zookeys.245.3416

[32] Smith, J., Potts, S.G., Woodcock, B.A. and Eggleton, P. (2008) Can Arable Field Margins Be Managed to Enhance Their Biodiversity, Conservation and Functional Value for Soil Macrofauna? Journal of Applied Ecology, 45, 269-278. https://doi.org/10.1111/j.1365-2664.2007.01433.x

[33] Geiger, F., Wäckers, F.L. and Bianchi, F.J.J.A. (2009) Hibernation of Predatory Arthropods in Semi-Natural Habitats. Biocontrol, 54, 529-535. https://doi.org/10.1007/s10526-008-9206-5

[34] Cividanes, F.J., Barbosa, J.C., Martins, I.C.F., Pattaro, F., Nunes, M.A. and Santos, R.S. (2009) Diversity and Spatial Distribution of Ground Arthropods in Agroecosystems. Bragantia, 68, 991-1002.

https://doi.org/10.1590/S0006-87052009000400020 